\title{
II. RÁKÓCZI FERENC KÁRPÁTALJAI MAGYAR FŐISKOLA
}

II. Rákóczi Ferenc Kárpátaljai Magyar Főiskola

Cím: Beregszász, Kossuth tér 6.

Honlap: http://kmf.uz.ua/hu

E-mail: foiskola@kmf.uz.ua

Apáczai Csere János Könyvtár

Cím: Beregszász, Kossuth tér 6.

Honlap: http://kmf.uz.ua/hu/a-foiskola-egysegei/apaczai-csere-janos-konyvtar

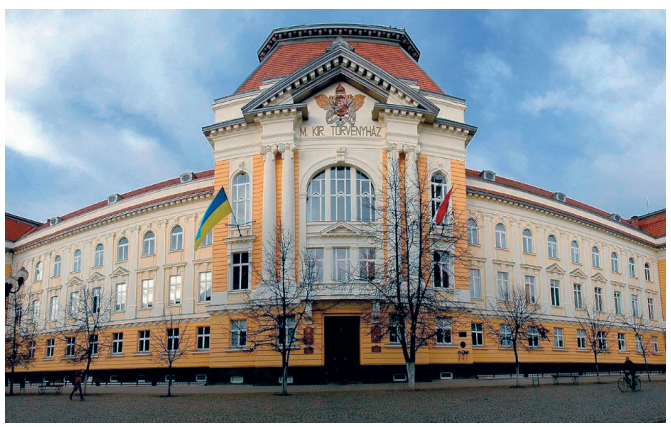

A II. Rákóczi Ferenc Kárpátaljai Magyar Főiskola első tanéve 1994-ben indult mint a nyíregyházi Bessenyei György Tanárképző Főiskola kihelyezett képzése, majd két év múlva önálló, Ukrajnában bejegyzett intézménnyé vált. A Rákóczi Főiskola alapítványi jellegú intézmény, Ukrajnában a magánegyetem kategóriába tartozik. Jelenleg három szinten (szakgimnázium, BA, MA) és 12 szakon folyik akkreditált képzés, valamint 15 szakon nem akkreditált képzési programot kínálunk a továbbtanulni óhajtóknak.

Az intézmény létrejöttével egy időben alakult a könyvtár is, egy kölcsönzői és egy olvasótermi részleggel. 2005-ben a főiskola oktatási célra megkapta az egykori Bereg Megyei Törvényszék épületét Beregszász központjában, és a könyvtár teljes állománya is ide került áthelyezésre. Ekkor vettük fel az Apáczai Csere János Könyvtár nevet. A főiskola Információs Központjának egyik szervezeti egysége vagyunk. Mivel a termeink felújításához magyarországi megyék közgyúlései és városi önkormányzatai is hozzájárultak, ezért részlegeink termei róluk kapták neveiket.

Jelenleg 580 négyzetméteren, hat részlegen dolgozunk: központi olvasóterem (Vas megye), szakirodalmi- (Pápa) és szépirodalmi kölcsönző (Békéscsaba), folyóirat-olvasó és médiatár, kézirattár (Tolna megye), régi kiadványok (Vác) és tankönyvek tára (Szabolcs). Ezen kívül a Calibre e-könyv-kezelő rendszerében az intézmény saját elektronikus könyvtárat is gondoz. Az állományt

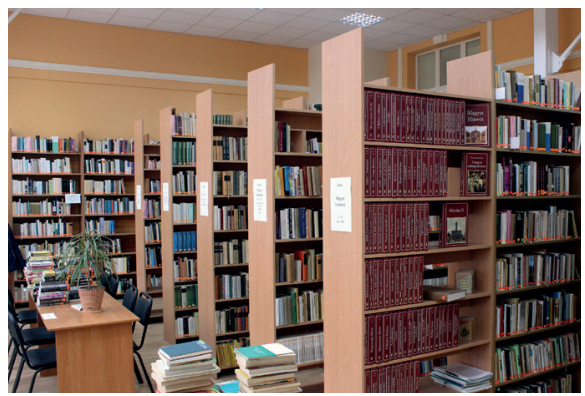




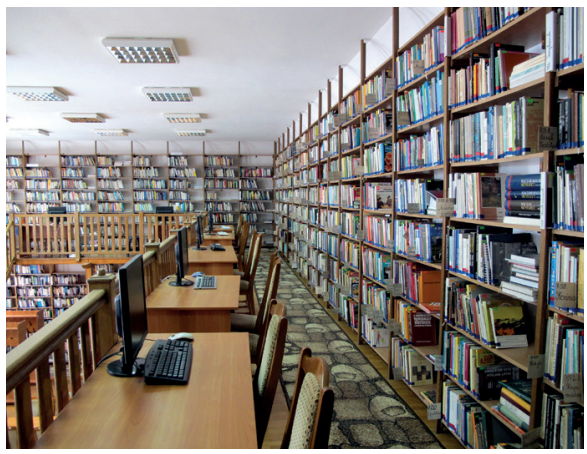

az Egyetemes Tizedes Osztályozás szerint osztályozzuk az e-Corvina könyvtári rendszerben. A teljes könyvtári állomány elektronikusan feldolgozott, a világ bármely részéről elérhető online katalógussal rendelkezünk. Könyvtárunk elsősorban a Rákóczi Főiskola oktató, nevelő és kutató munkáját segítő tudományos intézmény, ezért korlátozottan nyilvános könyvtár (nem közkönyvtár). A dokumentumokhoz történő hozzáférést azonban minden érdeklődő számára lehetővé tettük a látogatójegy bevezetésével, helybenhasználati joggal. A 2020. júniusi állapotok szerint a teljes könyvtári állományunk meghaladja a 120 ezer dokumentumot.

A könyvtár gyüjtőköre a Kárpátalján, illetve a Kárpátaljáról máshol kiadott dokumentumok. Állományunk elsősorban magyar nyelvű, ám az államnyelvű állományrész is több mint 30\%-ot tesz ki. Emellett angol, német, orosz, francia, szlovák és cseh nyelvű kiadványaink vannak. Jelen állapotunkban Kárpátalján könyvtárunk a leggazdagabb anyanyelvű szakkönyvtár.

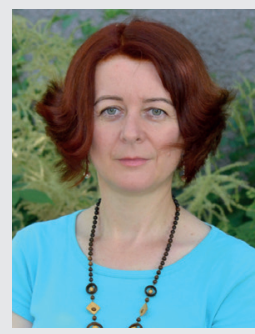

Szamborovszkyné dr. Nagy Ibolya

Könyvtárigazgató, történész. Történelem tanári oklevelét az Ungvári Állami Egyetemen szerezte, majd 12 évet dolgozott középiskolában. 1999-től óraadó, 2001-től fóállású oktatója lett a II. Rákóczi Ferenc Kárpátaljai Magyar Főiskolának. 2005-ben meghívásos pályázat útján lett az Apáczai Csere János Könyvtár igazgatója, miközben óraadó oktatója is maradt a Történelem és Társadalomtudományi Tanszéknek. Egyetemi doktori fokozatát az ELTE-n szerezte (Kelet-Európa története szakirányon). A mai napig folytat történeti kutatásokat. 